\title{
AN ANALYSIS OF STUDENTS GEOMETRY SKILLS WITH DIFFERENT VISUAL-SPATIAL AND LOGIC- MATHEMATIC INTELLIGENCE IN SOLVING THE PROBLEM OF SOLID PLANE GEOMETRY
}

\author{
Desi Puji Astuti ${ }^{*}$, Sutopo ${ }^{2}$, Farida Nurhasanah ${ }^{3}$ \\ 1,2,3Prodi Pendidikan Matematika, Fakultas Keguruan dan Ilmu Pendidikan, Universitas Sebelas Maret \\ ${ }^{2}$ Nama Institusi, Fakultas, Universitas/Institut, Kota, Negara

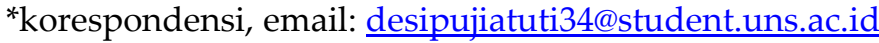

\begin{abstract}
Abstrak: Makalah ini bertujuan untuk mengetahui keterampilan geometri siswa dengan tingkat kecerdasan visual-spasial dan logika-matematika yang berbeda dalam menyelesaikan masalah permukaan bidang geometri padat. Ini adalah penelitian deskriptif kualitatif. Wawancara dan tes dilakukan untuk mendapatkan data tentang kemampuan geometri siswa dalam menyelesaikan masalah bidang bidang geometri padat. Hasil penelitian menunjukkan bahwa siswa dengan kecerdasan visual-spasial rendah dan kecerdasan logika-matematika rendah memiliki keterampilan visual level 0 , keterampilan verbal tidak mencapai level 0 , keterampilan logika tidak mencapai level 0, keterampilan menggambar mata pelajaran RR1. Level 0 dan subjek RR2 tidak mencapai level 0 , dan keterampilan terapan level 1. Siswa dengan kecerdasan visual-spasial rendah dan kecerdasan logika-matematika tinggi memiliki keterampilan visual level 0 , keterampilan verbal level 2, keterampilan logis level 1, keterampilan menggambar tingkat 1 , dan keterampilan terapan tingkat 1 . Siswa dengan kecerdasan visual-spasial tinggi dan kecerdasan logika-matematika rendah memiliki keterampilan visual tingkat 0 , keterampilan verbal tingkat 2 , keterampilan logika tingkat 0 , keterampilan menggambar tingkat 0 , dan keterampilan terapan tingkat 1 . Siswa dengan kecerdasan visual-spasial tinggi dan kecerdasan logika-matematika tinggi memiliki keterampilan visual tingkat 0 , keterampilan verbal tingkat 2 , keterampilan logika tingkat 1 , keterampilan menggambar tingkat 1 , dan keterampilan terapan tingkat 1 .
\end{abstract}

Kata kunci : Kemampuan komunikasi matematis, Mind mapping, Inside outside circle

Abstract: This paper aims to find out the geometry skills of students with different levels of visual- spatial and logic-mathematic intelligence in solving the problem of solid geometry plane surfaces. It is qualitative descriptive research. Interview and test were employed to get data about students' geometry skills in solving the problem of solid geometry plane surfaces. To maintain the worthiness of the data, the researcher implemented the time triangulation method. The data analysis comprised of data reduction, data display, and verification. This research used purposive sampling to determine the subjects. The results of this research indicated that the students with low visual-spatial intelligence and low logic-mathematic intelligence had visual skills level 0 , the verbal skills did not reach level 0 , the logical skills did not reach level 0 , drawing skills of subject RR1 was level 0 and subject RR2 did not reach level 0, and applied skills level 1 . The students with low visual-spatial intelligence and high logic-mathematic intelligence had visual skills level 0 , verbal skills level 2, logical skills level 1, drawing skills level 1, and applied skills level 1 . The students with high visual-spatial intelligence and low logic-mathematic intelligence had visual skills level 0, verbal skills level 2, logical skills level 0, drawing skills level 0 , and applied skills 
level 1 . The students with high visual-spatial intelligence and high logic-mathematic intelligence had visual skills level 0 , verbal skills level 2, logical skills level 1, drawing skills level 1, and applied skills level 1 .

Keywords : Geometry skills, Logic-mathematic intelligence, Visual-spatial intelligence, Solid geometry plane surface

\section{INTRODUCTION}

One of the studies in mathematics was geometry. According to KBBI, geometry is a branch of mathematics that describes the nature of lines, angles, areas, and space. Based on the results of Junior High School national examination year 2017/2018 in mathematics, students' absorption of geometry was $41.40 \%$ at the national level. The students' absorption at the Central Java was $43.07 \%$. Meanwhile, the students' geometry absorption at the Surakarta was still low, with 53.70\%. Similar to the national examination results at SMP Al- Irsyad Surakarta, it indicated that the students' geometry absorption was still low, with $47.55 \%$. It can be concluded that the students' absorption of geometry is low; therefore, geometry is crucial to be learned and becomes an essential concern.

According to Van De Walle in Sofyana \& Budiarto (2013), there are five reasons on how important to learn geometry is. They comprise (1) Geometry can provide a more complete appreciation of the world, (2) Geometric explorations can develop problem- solving skills, (3) Geometry plays a crucial role in the study of other areas of mathematics, (4) Geometry is used daily by many people, and (5) Geometry is enjoyable. According to Ruseffendi, the object of which is directly related to mathematics learning activities includes facts, skills, concepts, and rules/principles (Muhassanah, Sujadi, \& Riyadi, 2014). Based on Ruseffendi's study, skills are needed to learn geometry. It is therefore necessary to know in advance how and to what extent the student masters the skills. According to Hoffer (1981), there are five skills in the study of geometry: (1) visual skills, (2) verbal skills, (3) drawing skills, (4) logical skills, and (5) applied skills. Additionally, according to Hoffer (1981), the levels of geometric derives from Van Hiele include level 0 (visualization), level 1 (analysis), level 2 (informal deduction), level 3 (deduction), and level 4 (rigor). One of the geometry materials that become a concern at school is solid plane geometry, there are cubes, blocks, prisms, and pyramids. In the national examination, there are several questions related to solid geometry plane surfaces. In the process of thinking about solving geometry problems, certainly logical-mathematical and visual-spatial intelligence are needed. It is consistent with the results of research from Putri (2017), which states that there is a positive influence between spatial ability on the geometry ability of students. Rahbarnia research results (Arum, et al., 2018) also showed a positive correlation between logical-mathematical intelligence in solving mathematical problems. Similarly, according to Rozalinah (2016), there is an influence between the 
logical-mathematical and visual-spatial intelligence to students' problem-solving geometry ability of class IX SMP/MTs in the district Panceng. According to Chatib \& Said (2012), logical-mathematical intelligence is intelligence that is related to the ability of reasoning and calculation that exists in students, while visual-spatial intelligence is intelligence that is related to spatial abilities. Ahvan, et al. (2015) also states that visual-spatial and logical-mathematical intelligence are the best predictors of academic achievement.

The purpose of this study are: (1) to describe geometry skills of students with low visual-spatial intelligence and low logical-mathematical intelligence in solving solid plane geometry, (2) to describe geometry skills of students with low visual-spatial intelligence and high logical-mathematical intelligence in solving solid plane geometry, (3) to describe geometry skills of students with high visualspatial and low logical-mathematical intelligence in solving solid plane geometry, and (4) to describe geometry skills of students with high visual-spatial and high logical-mathematical intelligence in solving solid plane geometry.

\section{METHODOLOGY}

This research is a qualitative descriptive study. The students of class VIII A-PK and VIII B-PK SMP Al-Irsyad Surakarta were involved. The researcher used purposive sampling to determine the subject. There were two students with low visual-spatial intelligence and low logical-mathematical intelligence, one student with low visual-spatial intelligence and high logical-mathematical intelligence, one student with high visual-spatial intelligence and low logical-mathematical intelligence, and one student with high visual- spatial intelligence and high logical-mathematical intelligence. Tests and interviews were employed to collect the data. To maintain the worthiness of the data, the researcher used the time triangulation technique. The data analysis technique included reduction, data presentation, and conclusions.

The pre-research procedures involved designing a research proposal, permitting to the relevant institutions, designing research instruments. The fieldwork phase involved giving intelligence tests of visual-spatial and logical-mathematical, providing skill tests geometry, as well as conducting interviews with the subjects. The data analysis phase included reducing the data reduction, displaying the data, drawing conclusions, and validating the data. Finally, after the data had been collected and analyzed, the researcher wrote a final report.

According to Jabar and Noor (2015) study at junior high school, students with level 0 (visualization) is $8 \%$, level 1 (analysis) is $32 \%$, level 2 (deduction informal) is $40 \%$ as well as students who reach level 3 (formal deduction) is only $1 \%$, and level 4 (rigor) is $0 \%$. It means that junior high 
school students generally reach level 2 (deduction informal) of geometry thinking, so the problems that will be used is about at level 0 to 2 .

Table 1. Geometry Skills Indicators in the solid geometry plane surface material based on Hoffer

\begin{tabular}{|c|c|c|}
\hline Skills & Level & Indicator \\
\hline \multirow[t]{3}{*}{ Visual } & 0 & Can recognize the different figures of solid plane geometry \\
\hline & 1 & Can notice the properties of figures \\
\hline & 2 & Can recognize interrelationships between different types of figures \\
\hline \multirow[t]{3}{*}{ Verbal } & 0 & Can classify the name of a given solid plane geometry \\
\hline & 1 & Can describe accurately various properties of a figure \\
\hline & 2 & Can formulate accurate and concise definitions \\
\hline \multirow[t]{3}{*}{ Drawing } & 0 & Can make sketches of figures accurately and label each part \\
\hline & 1 & Can use the given properties of figures to draw or construct the figures \\
\hline & 2 & Can give a specific figure and construct another figure related to the given Ones \\
\hline \multirow[t]{3}{*}{ Logical } & 0 & Can realize that there are differences and similarities among figures \\
\hline & 1 & Can understand that figures can be classified into different types \\
\hline & 2 & $\begin{array}{l}\text { Can use properties of figures to determine whether or not one class of figures } \\
\text { is contained in another class }\end{array}$ \\
\hline \multirow[t]{3}{*}{ Applied } & 0 & Can identifiy solid plane geometry in the physical object \\
\hline & 1 & Can recognize geometric properties of the physical object \\
\hline & 2 & $\begin{array}{l}\text { Can understand the concept of a mathematical model that represents } \\
\text { relationship between the objects }\end{array}$ \\
\hline
\end{tabular}

The categorization of visual-spatial intelligence and logical-mathematical intelligence based on Carter (2009).

Table 2. Category of Intelligence According to Philip Carter

\begin{tabular}{cc}
\hline Category & Score \\
\hline Extraordinary & 10 \\
Superior & $8-9$ \\
Very Good & 7 \\
Well & $5-6$ \\
Average & 4 \\
\hline
\end{tabular}

Table 3. Category of Intelligence in This Research

\begin{tabular}{cc}
\hline Category & Score \\
\hline High & $7 \leq \mathrm{x} \leq 10$ \\
Moderate & $4 \leq \mathrm{x} \leq 7$ \\
Low & $0 \leq \mathrm{x} \leq 4$ \\
\hline
\end{tabular}

\section{RESULT AND DISCUSSION}

Tests of visual-spatial and logical-mathematical intelligence were held on March 28th, 2019. Then the students were given a test of skill geometry. After seeing the results of visual- spatial and logicalmathematical intelligence tests grouped by category, and seeing the answers to geometry skills tests, the researcher selected five subjects to be interviewed. The subjects were two subjects with low visualspatial intelligence and low logical-mathematical intelligence (RR1 and RR2), one subject with low visual-spatial intelligence and high logical-mathematical intelligence (RT), one subject with high visual- 
spatial intelligence and low logical-mathematical intelligence (TR), and one subject with high visualspatial intelligence and high logical-mathematical intelligence (TT).

Based on the exposure data and analysis that have been done, the geometry skills of students with visual-spatial intelligence and logical-mathematical intelligence in solving solid plane geometry were revealed.

1. Geometry Skills of Students with Low Visual-Spatial Intelligence and Low Logical- Mathematical Intelligence

The finding revealed that RR1 and RR2 could recognize and mention the various names of solid plane geometry, but could not indicate the requested properties. Meanwhile, RR1 and RR2 were still confused about space diagonal and diagonal plane; therefore, they were wrongly showing the answer. It indicated that the students' visual skills possessed at level 0.

Further, RR1 and RR2 could find a description that indicated a solid geometry plane yet were not able to find all the appropriate columns. It indicated that the students can not classify the name of a given solid plane geometry, so the students' verbal skills did not reach level 0 .

RR1 could not see the similarity of the properties between two figures. The differences were not written entirely. Similarly, the subject RR2 was not able to precisely locate the similarities and differences between the two figures. It shows that the logical skills of RR1 and RR2 did not reach level 0 . The following figure is the work of the students.

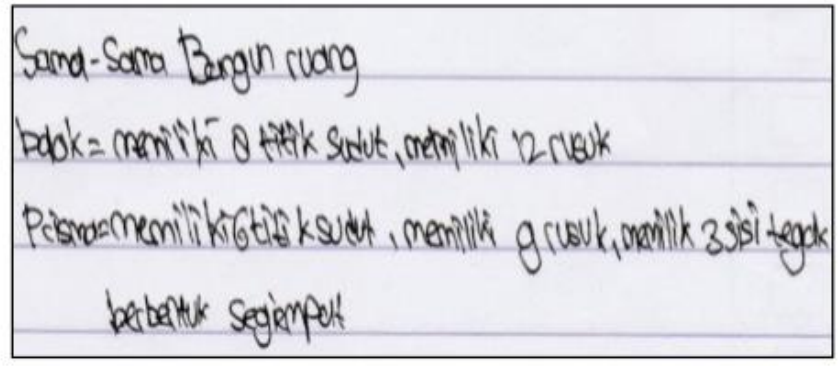

Figure 1. RR1's Answer Sheet of Geometry Skills Test I No.3a and 3b

RR2 could sketch the requested geometry, yet was not labeling the figure. Meanwhile, RR1 could sketch and even label a requested figure as shown in the following figure.

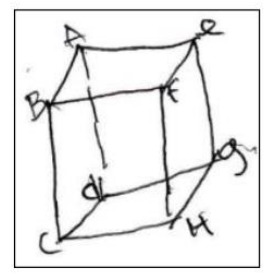

Figure 2. Sketh Made by RR1 on Interview I 


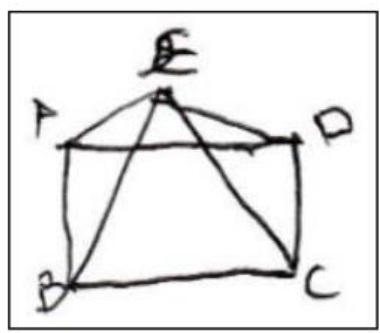

Figure 3. Sketch Made by RR1 on Interview II

Furthermore, RR1 and RR2 did not sketch a figure according to the description, although they knew what the description meant. It showed that RR1 had level 0 at drawing skills, and RR2 did not reach level 0.

RR1 and RR2 could identify solid plane geometry in the physical object and could recognize the properties of the physical object. However, they could not calculate the volume and surface area as well as apply the formula in the object. It indicated that RR1 and RR2 had level 1 at applied skills.

Although RR1 and RR2 had the same level of intelligence, there were still differences in their drawing skills. These differences occurred because RR2 was still entirely confused when asked to sketch a solid geometry plane so that sometimes he was drawing inappropriately and lacking in labeling. Confusion might occur because RR2 was not accustomed to the form of solid geometry in detail, for example, simply call a pyramid or prism, instead of a triangular prism, quadrilateral pyramid, and more. It is therefore the applied skills of RR1 and RR2 were at level 1. It might occur because, in applied skills, the picture shown was an image of objects that exist around the subject. Thus, the subject was able to recognize their physical characteristics, even though the visual skills of RR1 and RR2 could not show the requested geometrical properties.

2. Geometry Skills of Students with Low Visual-Spatial Intelligence and High LogicalMathematical Intelligence

Subject RT could recognize the different figures of solid plane geometry with a reason, but he could not show the requested properties. RT was still confused about the properties of the solid plane geometry. It indicated that the visual skills of RT at level 0.

Moreover, RT could find all columns that described the requested solid plane geometry. RT could also describe the properties of the requested solid plane geometry and make the definition of that. It showed that RT's verbal skills at level 2. 


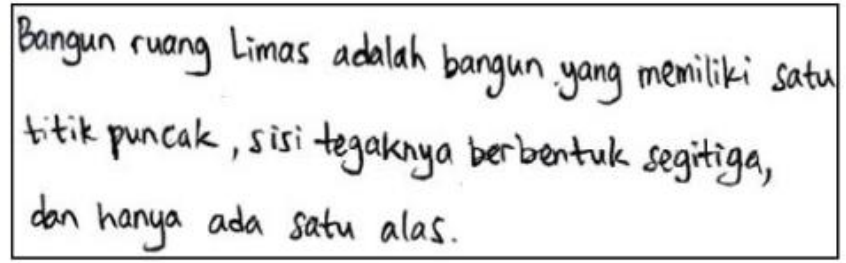

Figure 4. RT's Answer Sheet of Geometry Skills Test No. 2c

RT could recognize the similarities and differences between the two solid plane geometry. RT could also understand that specific figures could be classified into different types. However, they could not use the exact properties of those figures to determine whether or not they contained in another class. It showed that RT's logical skills were at level 1.

Moreover, RT could sketch the requested solid plane geometry and give the label. Subject RT could also sketch or create geometrical drawings following the description being given, that are having 9 ribs with a length of $5 \mathrm{~cm}, 6$ vertex points, 2 triangular shaped sides, and 3 rectangular shaped sides. The following figures are the students' results in illustrating solid plane geometry.

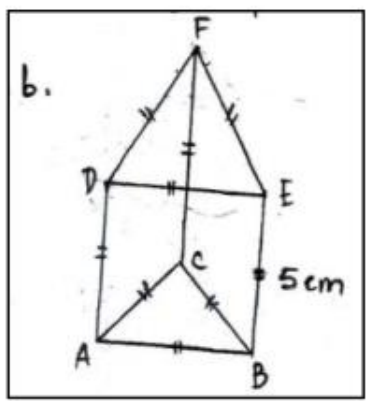

Figure 5. RT's Answer Sheet of Geometry Skills Test I No.4b

RT are also asked to draw sketches with the characteristics of having 12 ribs, 8 vertex points, 4 ribs on the base and lid, 4 rectangular shaped on vertical sides, the opposite sides are congruent, length of base ribs is $2 \mathrm{~cm}$ and for vertical ribs is $4 \mathrm{~cm}$. The following figures are the students' results in illustrating solid plane geometry.

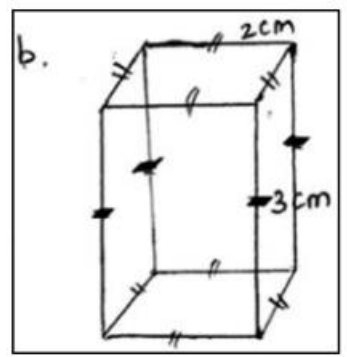

Figure 6. RT's Answer Sheet of Geometry Skills Test II No.4b 
Figure 5 and figure 6 showed that RT made a geometrical sketch by providing information according to the given description. RT could not construct another figure related to the given ones; thus, he had level 1 at drawing skills. RT could identify solid plane geometry in physical objects and recognize the physical properties of those objects. However, RT was not able to apply mathematical concepts into the object, which was indicated his inability to find out the surface area and volume of the object. Basically, RT learned the formula that could be applied to the object. In certain parts, RT did not know how to apply them. It showed that RT had level 1 at applied skills.

From the previous analysis, it can be identified that RT's verbal skills at level 2 and logical skills at level 1, but for the visual skills of RT at level 0. At the test of logic skills, verbal skills, and visual skills equally related to the characteristics or properties of a structure, but the results could be different. It might occur because of visual skills influence. The subjects were asked to indicate the properties of solid plane geometry that require sight or observation; thus, it indicated that visualspatial intelligence played a significant role. Meanwhile, at the verbal skills and logical skills, the subject was only asked to mention the properties that might be influenced by the capacity of the subject's thought. Besides, the description of some solid plane geometry was provided in verbal skills. Therefore, RT could conclude based on the description by paying attention to the relationship between the descriptions.

3. Geometry Skills of Students with High Visual-Spatial Intelligence and Low LogicalMathematical Intelligence

TR could recognize and mention the name of different figures with a reason, but he could not indicate the requested properties. It happened because TR did not adequately nderstand the properties of solid plane geometry; thus, he made a mistake when showing the required properties. It revealed that TR had level 0 at visual skills. Further, TR could find all the columns that contain the requested descriptions of solid plane geometry as well as give a reason in selecting those columns. Subject TR could also describe the properties of the requested solid plane geometry, as stated in the following interview.

$\mathrm{P} \quad$ : "Hem yes. Now try to make a definition of pyramid!"

TR : "A pyramid is a solid geometry that has one base, a cusp, and also the upright side is triangular in shape."

This following picture is the answer written on TR's geometry skills tests. 


$$
\begin{aligned}
& \text { bangun ruang prisma adalah bangun } \\
& \text { ruang yang memiliki tutv } \\
& \text { alas dan tidak memitiki titik puncak }
\end{aligned}
$$

Figure 7. TR's Answer Sheet on Geometry Skills Test II No.2c

Based on interviews and answer sheets, it was known that TR could make the definition of the requested geometry. It pointed out that TR had level 2 at verbal skills. Further, TR could recognize and mention the similarities and differences between the two requested figures, yet he did not classify a particular solid plane geometry into another type. It showed that TR had level 0 at logical skills.

TR could draw or sketch the requested solid geometry, that are prism and pyramid, and give a label; however, he was not able to sketch solid geometry following the given description. It indicated that TR had level 0 at drawing skills. Figure 8 and Figure 9 below shows the geometrical drawings made by TR for prism and pyramid.

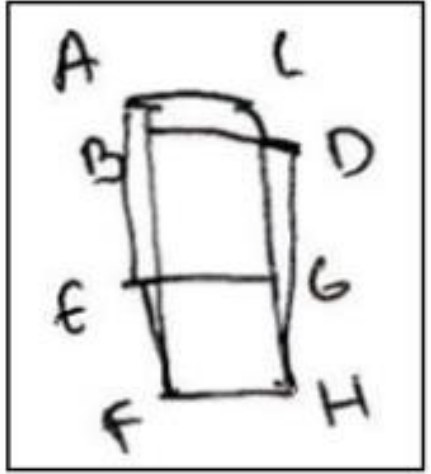

Figure 8. Sketch Made by TR on Interview I

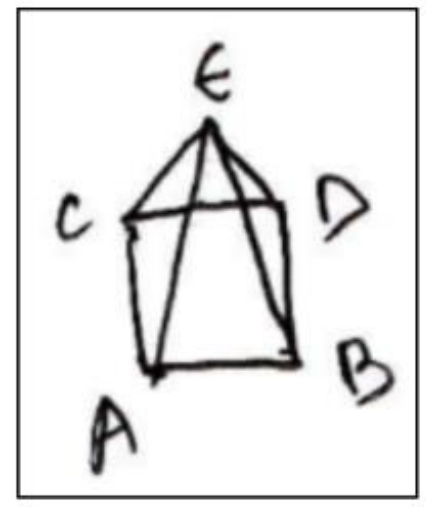

Figure 9. Sketch Made by TR on Interview II

Furthermore, TR could identify the requested solid plane geometry in physical objects. TR could also mention the physical properties of the object, but he was not able to implement a 
geometrical formula to find the volume and surface area of the object. TR found confusion in finding the size of the object in question; hence, he could not use the formula. It pointed out that TR had level 1 at applied skills.

4. Geometry Skills Students with High Visual-Spatial Intelligence and High LogicalMathematical Intelligence

TT could recognize and mention the name of the different figures with reasons. However, when TT was asked to indicate the properties of the requested, namely space diagonal and plane diagonal, he made a mistake. It pointed out that TT had level 0 at visual skills.

TT could find all columns containing a description of the requested solid geometry and the reasons for choosing those columns. TT could also interpret sentences in the description; hence, they could choose specific columns. TT could provide a reason or a key in selecting the column, for instance, pyramid having a cusp so that he chose the column that had the description. Furthermore, TT identified the reason by counting the ribs described in the selected columns earlier. While opting for a column that contained a description prism, he considered a description that had the base and lid, then looked at the shape of the upright. The way TT in choosing this column was already well structured. TT was able to describe the properties of the pyramid and prism in general. He did not refer to one form of each solid geometry or referring to one column that described solid geometry. It indicated that TT had already understood the properties and characteristics of a solid geometry broadly and presented all forms of the requested solid geometry. TT could define pyramid and prism that could to be applied to all forms. It pointed out that TT had level 2 at verbal skills.

TT could recognize and mention the similarities and differences of the requested geometry. TT could also classify particular solid geometry in other types using geometrical properties. However, TT could not provide the conditions for solid geometry that could be referred to another class. It showed that TT has level 1 at logical skills. Further, TT could sketch the requested solid plane geometry. The following figure shows the drawings made by TT.

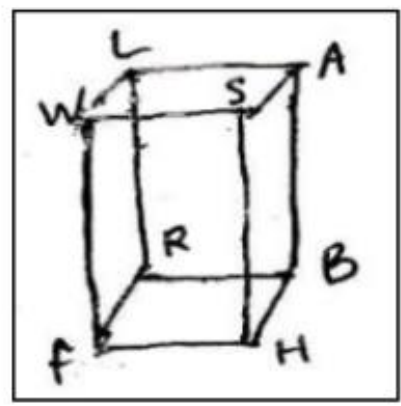

Figure 10. Sketch Made by TT on Interview I 


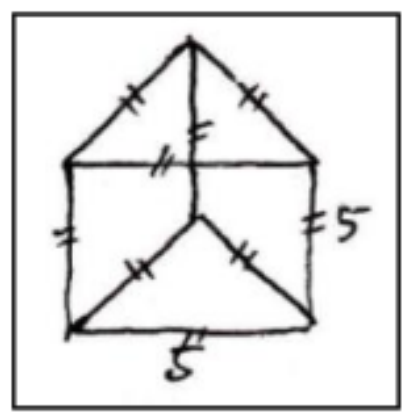

Figure 11. Sketch Made by TT on Interview II

In Figure 11, it can be seen that TT can sketch a prism according to the characteristics mentioned, which has 9 ribs with a length of $5 \mathrm{~cm}, 6$ vertex points, 2 sides of a triangle, and 3 sides of a square. It showed TT could sketch the requested solid plane geometry that fitted to the description. TT could not construct another figure of solid plane geometry from the given figure. It pointed out that TT has level 1 at drawing skills.

TT could identify the requested solid plane geometry in physical objects. TT could also mention the physical properties of the object, indicating that the object was indeed the solid geometry. Nevertheless, TT could not seek the surface area and volume of the object. TT was having confusion when trying to apply the known formula because he did not know the actual size. It showed had TT has level 1 at applied skills.

Based on the previously presented analysis, it can be summarized that students with different levels of intelligence had different skill levels. It was discovered that students with different levels of intelligence had the same level of visual skills and applied skills. This study also revealed that visualspatial intelligence was not a significant difference in the geometry skills of the students. Logicalmathematical intelligence provided a significant difference, as shown by the students with low visualspatial intelligence and high logical-mathematical intelligence had better geometry skills than students with high visual-spatial intelligence and low logical-mathematical intelligence. It was entirely different from Hayati's research (2017), which revealed that visual skills and applied skills of students with high visual-spatial intelligence was better than students with low visual-spatial intelligence.

Those differences might be due to the experience of the subject, such as the ability to observe and indicate the properties of solid geometry through the image was still low. Thus, the subject was not accustomed to the use of visual skills. It showed that if the learning strategies used were different, the attention and interest shown by students would also be different. It would affect the level of geometry skills and certainly give different learning outcomes. It was in accordance with research 
conducted by Sood (2013) and Fadillah (2013) land Uno (1996), who concluded that the teaching strategies used could influence students learning outcomes in geometry.

\section{CONCLUSIONS AND RECOMMENDATION}

Based on previously explained findings, the researcher concluded that students with low visualspatial and low logical-mathematical intelligence have visual skills at level 0. Meanwhile, students' verbal skills do not reach level 0, as well as their logic skills do not reach level 0. RR1 and RR2 have a different level of drawing skills, respectively, level 0 and below level 0 . Both subjects have level 0 at applied skills. Further, students with low visual-spatial intelligence and high logical-mathematical intelligence have visual skills at level 0 , verbal skills at level 2, logical skills at level 1, drawing skills at level 1, and applied skills at level 1. Students with high visual-spatial intelligence and low logicalmathematical intelligence have visual skills at level 0 , verbal skills at level 2, logical skills at level 0 , drawing skills at level 0 , and applied skills at level 1 . Students with high visual-spatial intelligence and high logical-mathematical intelligence have visual skills at level 0 , verbal skills at level 2 , logical skills at level 1, drawing skills at level 1, and applied skills at level 1.

This study can be used for teachers in designing a suitable learning model in the classroom, for instance, the discovery learning model. That model helps students to understand the concept of the material because they will be directed to find things related to learning, such as the formula contained in the material so that they have long term memory toward the lessons being learned. Students need more practice in solving varied problems about solid plane geometry, such as open-ended questions or critical thinking questions. In solving the problems, students have to be able to understand the words contained in the question; clearly, they should be able to interpret what the problems mean. The students need to pay attention to the details of the problems by making a note. Furthermore, students should remember the concepts of the material that may be related to the information in the questions and choose the right formula to be used in solving problems. Students also have to write answers clearly, and write the answers in sentence form if needed. If the students find it difficult, they may create an illustration to help to remember the concept or see the relationships among the problems.

For other researchers who have the same interest, they further may try to explore different materials and levels with the same or another point of view. The views may comprise based on cognitive style or learning style. Another preference may only focus on one skill that contains geometry skills. Finally, the results of this study can also be used for comparison and reference for similar research. 


\section{REFERENCES}

Arum, Kusmayadi, \& Pramudya. (2018). Students' Logical-Mathematical Intelligence Profile. IOP Conf. Series: Journal of Physics: Conf. Ser. 1008012071

Ahvan, Y.R., Zainalipour, H., Jamri, M., \& Mahmoodi, F. (2015). The Correlation between Gardner's Multiple Intelligences and the Problem-solving Styles and their Role in the Academic Performance Achievement of High School Students. European Online Journal of Natural and Social Sciences, 5(1), 32-39. Diperoleh 25 November 2019, dari https://pdfs.semanticscholar.org

Carter, Philip. (2009). Tes IQ dan Tes Kepribadian. Terj. Ati Cahayani. Jakarta: PT Indeks

Chatib, M \& Said, A. (2012). Sekolah Anak-Anak Juara: Berbasis Kecerdasan Jamak dan Pendidikan Berkeadilan. Bandung: Kaifa

Fadillah. (2013). Pengaruh Penerapan Strategi Guided Note Taking Yang dipadukan dengan Strategi Everyone Is a Teacher Here Terhadap Keterampilan Pemecahan Masalah Geometri Pada Pokok Bahasan Segiempat. Skripsi. IAIN Syekh Nurjati, Cirebon.

Faller, Jubilo, Espera. (2016). E-Learning Approach and Logical Mathematical \& Spatial Intelligence in Learning Solid Geometry. The Asian Conference on Technology in the Classroom 2016: Official Conference Proceedings

Hayati, Puji. (2017). Analisis Tingkat Keterampilan Geometri Berdasarkan Tahap Berpikir Van Hiele Ditinjau dari Kecerdasan Spasial Siswa Kelas IX SMP Negeri 4 Bandar Lampung. Skripsi. Universitas Islam Negeri Raden Intan, Lampung

Hoffer. (1981). Geometry Is More Than Proof. NCTM Journal: The Mathematics Teacher, 74(1), 11-18

Jabar, A \& Noor, F. (2015). Identifikasi Tingkat Berpikir Geometri Siswa SMP Berdasarkan Teori Van Hiele. JPM IAIN Antasari, 2(2), 19-28

Muhassanah, N, Sujadi, \& Riyadi. (2014). Analisis Keterampilan Geometri Siswa Dalam Memecahkan Masalah Geometri Berdasarkan Tingkat Berpikir Van Hielle. Jurnal Elektronik Pembelajaran Matematika, 2(1), 54-66. Diperoleh 4 Januari 2019, dari https://jurnal.fkip.uns.ac.id/index.php/s2math/article/view/3639/2546

Putri, A.H. (2017). Pengaruh Kemampuan Spasial Terhadap Kemampuan Geometri Pada Peserta Didik Kelas VII SMP Swasta Di Kecamatan Kebomas Gresik. Jurnal Pemikiran Pendidikan, 23(2), 114121 Rozalinah, Ema. (2016). Pengaruh Kecerdasan Logis-Matematis dan Kecerdasan Visual Spasial Terhadap Kemampuan Pemecahan Masalah Geometri Peserta Didik Kelas IX SMP/MTS di Kecamatan Panceng. Thesis. Universitas Muhammadiyah, Gresik

Sofyana \& Budiarto. (2013). Profil Keterampilan Geometri Siswa SMP dalam Memecahkan Masalah Geometri Berdasarkan Level Perkembangan Berpikir Van Hiele. Jurnal Elektronik Matematika, 2(1), 98-105. $\quad$ Diperoleh 4 Januari 2019, dari https://jurnalmahasiswa.unesa.ac.id/index.php/mathedunesa/article/view/1220 
Sood, V. (2013). Effect of Mastery Learning Strategies on Concept Attainment In Geometry Among Highschool Students. International Journal of Behavioral Social and Movement Sciences, 2(2), 144-155. Diperoleh 25 November 2019, dari https://pdfs.semanticscholar.org

Uno, H.B. (1996). Pengaruh Strategi Pengajaran dan Gaya Kognitif terhadap Perolehan Belajar Geometri di Sekolah Menengah Umum. Jurnal Ilmu Pendidikan, 3(3), 211227. Diperoleh 12 Oktober 2019, dari http://journal.um.ac.id/index.php/jip/article/view/1749/1590 